\title{
Is Financial Advertisement Effectiveness is Dependent on the Type of Media? A Case of Print, Electronic and Online Media

\author{
Pallavi Dogra, Arun Kaushal
}

\begin{abstract}
The purpose of the paper is to compares the effectiveness of the three media i.e. newspaper, internet and the television utilized by the financial industry so as to get positive consumer attitude. The study identified the important factors present in the specific media which will increase the effectiveness and makes that media preferred ones as compared to other media. Primary data had been collected from the 481 respondents belonging to the northern part of India using the survey method. Exploratory Factor analysis, Confirmatory factor analysis and Manova test was applied to draw the findings. The result reveals that the internet and the newspaper financial advertisements provide the receiver the more detailed, trustworthy, and useful information. The results confirmed that information broadcasted on the television is much slower processed by the audience as compared to information broadcasted on the internet and newspaper. Making the comparison analysis between the three media, the derived results are beneficial for the advertisement designers and makers so that they can focus on the important factors while drafting the financial advertisements. Strategic managers and policymakers can get important insights about the most preferred media so that they can exploit that media which is more effective in bestowing the advertisements.
\end{abstract}

Keywords: Newspaper, internet, television, consumer attitude, financial service advertisements.

\section{INTRODUCTION}

The Internet is the result of the rise in technology and this is widely used in every sector. In the promotional and advertising field it is more utilized in the form of digital advertising, online advertising, youtube advertising, social media advertising, etc. This new advertising channel is widely utilized for the marketing of every type of financial product along with the traditional media channels such as magazines, radio, newspaper, TV, etc.

Manuscript published on November 30, 2019.

* Correspondence Author

Pallavi Dogra* Assistant Professor, Department of Business Management, GLA University, Mathura, India. E-mail: pallavi.dogra.123@gmail.com.

Arun Kaushal, Assistant Professor, Department of Business Management, GLA University, Mathura, India. E-mail: arun.kaushal@gla.ac.in.

(C) The Authors. Published by Blue Eyes Intelligence Engineering and Sciences Publication (BEIESP). This is an open access article under the CC-BY-NC-ND license http://creativecommons.org/licenses/by-nc$\mathrm{nd} / 4.0 /$
More and more media options availability results in the need to know the level of effectiveness of available media in meeting the desired objective (Dijkstra, 2005). Therefore, the media planners, advertising agencies should know the pros and cons of each available media and the recognition of the most effective media (Buchholz and Smith, 1991; Vakratsas and Ambler, 1999). Past researches provide evidence that the effectiveness of the advertisement depends upon the selected media (Sundar, 1998) and context variables (Bronner and Neijens, 2006). Several available studies identified the effects of print news media and online media (Cacciatore et.al, 2012), comparison of eight available media (Bronner and Neijens, 2006), radio, TV \& print media (Buchholz and Smith, 1991, Edell and Keller, 1989).

There exist numerous studies that analyzed the effectiveness, the media contribution in making the advertisement successful, but there is a dearth in the literature especially in the context of financial service advertisement and media effectiveness. Further, the effectiveness of the ad content in terms of consumers' attitudes towards the advertised financial service provider and their intentions across the country is required in a deeper sense. Therefore, the present research discusses the contribution of the three media in making the financial service advertisement the most-watched and resulting ineffectual. The three media investigated in the study includes Electronic media (television), Print media (newspaper) and online media (internet).

The purpose of the study is to analyze the factors in the context of media effectiveness which makes the financial advertisements effective on the traditional or electronic media. Therefore to make this comparison, attitude towards product/service provider, attitude towards advertisement, trustable and product planning variables were focused. In the following sections of the paper, discussion on the importance of the media sources used for the advertisement had been presented. The research instrument used in the study for the data collection had been presented with the address on the research methodology. Afterward, the collected data has been analyzed using the data analysis technique. Finally, the findings are discussed and the implications are presented.

\section{LITERATURE REVIEW}

The advertisement has a strong connection with the entertainment and type of media. The advertisement is an effective way to motivate consumer's emotionally to shop the products (Moore, 2004). Picken (1999) found that advertisement is unavoidable and it is present on every media like TV, radio, newspapers, magazines, hoardings, mailboxes, trains, buses and the Internet. Saha et al. (2007) 
found that various advertising agencies use the television to advertise their products and services intended to target prospective and existing customers. The purchase behavior of the customers can be encouraged due to free coupon in print advertisement or special slogan used in the television advertisement which will provide the customer at the time of purchase (Zinkhan et al., 1992). Karniouchina et al. (2009) demonstrated that stock advertisements that affect the investor's decision include the message length, information and source credibility. There are various studies presented the effectiveness of the television advertisement like Luo and Donthu (2005) opined that advertising spending in print, broadcast, and outdoor media are inefficient and could bring in 20 percent more sales.

Table 1: Review on "television advertisement" used as media for the financial service advertisement

\begin{tabular}{|c|l|}
\hline Constructs & \multicolumn{1}{|c|}{ Researchers \& Year } \\
\hline \multirow{5}{*}{ Television advertisement } & Aydogdu and Wellman (2011), \\
& Devi, and Joseph, (2017), Taha and \\
& Palmiter (2011), Karniouchina, \\
& Moore, \& Cooney (2009), Pieters, \\
& and Bijmolt (1997), Palmiter and \\
& Taha (2008), Cronqvist (2005), \\
& Soni (2017), Neza and Myftaraj \\
& (2016), Howcroft, Hamilton \\
& \&Hewer (2007), Mogaji, \\
& Czarnecka, and Danbury (2018), \\
& Fam and Waller (2006) \\
\hline
\end{tabular}

\subsection{Television advertisement}

Television advertising is good for transformational strategies as it provides more entertainment value (Mittal, 1994). Neza and Myftaraj (2016) opined that insurance companies are putting a lot of efforts on the advertisement on television, print, radio or leaflets for the image building. Aydogdu and Wellman (2011) found that in the case of mutual fund advertisements TV advertisements are most effective and most of the companies spend huge money on them. Viswanathan and Hastak (2002) found that television advertisements guide investors in making Inter brand judgments by doing a product category comparison. Cronqvis (2005) found that television advertisement affects the investor's mutual fund portfolio selection. Soni (2017) opined that effective advertisements are more effective in high involvement products as compared to low involvement products.

Howcroft et al. (2007) found that television advertisement effectiveness is more as compared to reading any printed information. Pieters and Bijmolt (1997) television advertisement duration have the largest effect size on the brand name recall. Palmiter and Taha (2008) found that in television advertisements investors read the mandatory warning disclosures. Pieters and Bijmolt (1997) found that consumers recall memory is affected by both the duration of the commercial and competition. Devi and Velanganni (2017) suggested that mutual fund companies should conduct seminars, give television advertisements and organize lectures or talk show by the Analysts and Chartered accountants to reach investors. According to Haidi and Malik (2006) found that exposure and knowledge of Islamic banking are through one's effort before property purchase, recommendation by friends, through working experience and advertisement and promotions.
The voice of the spokesperson in television advertisement carries much importance as compared to the images used in the print media (Mogaji et al . 2018). The information about stock prices to which investors were bombarded by the various media such as magazine articles, television shows and, e-mails do not affect the investors (Frieder and Zittrain, 2007). Palmiter and Taha (2011) found that mutual funds advertisements are highly misleading and inadequate. These advertisements are highly ineffective due to the false claims regarding the past performance of funds.

\subsection{Newspaper advertising}

The development of the media industry is largely contributed by newspaper advertising and still occupies the major share in the advertisement industry (Dash and Belgaonkar, 2012). The "degree of attention or level of involvement" and "energy devoted to message understanding" is higher in newspaper media (James and Kover, 1992). The level of involvement and attention is higher in the case of newspaper advertising because the search for information is not interrupted (James and Kover, 1992; Mittal, 1994; Tan and Chia, 2007). The appeals targeting the emotions of the people in case of financial service advertisements are still of importance even there is a decline in readership (Ponsford, 2015).

Cutler and Javalgi (1993) found that in-service marketing no one quality claims which generate ambiguity and uncertainty. The service advertisement consists of emotional appeal. Mittal (1994) found that print media provide more informational advertising strategies and perceived as more informative than television media. James and Kover (1992) opined that the newspaper provides the choice to the reader to read or skip the advertisement as compared to television media. But Smit (1999) found that when the reader read the advertisement, readers get more involved in reading the advertisement. This finding is closely associated with the Newswork (2014) who found that reading a newspaper bought a greater level of engagement, emotional attachment, and more time spending.

The following sections present the various studies on the topic of newspaper advertisement related to the effectiveness of advertisement in various sectors such as banking, mutual fund and insurance advertisements in newspapers. The previous targets on the various dimensions such as the content of the advertisement, quality, transparency, benefits, message graphics and ethical parameters in the newspaper advertisements and so on. Table 2 presents the summarized view of previous studies done in the field of newspaper advertisements.

Table 2: Review on the "Newspaper" used as media for the financial service advertisement

\begin{tabular}{|c|c|}
\hline Constructs & Researchers \& Year \\
\hline Newspaper media & $\begin{array}{l}\text { Devi and Joseph (2017), Methaq \& } \\
\text { Abdulmajid (2011), Olbrich, Rainer } \\
\text { and Schultz (2014), Ekerdt and } \\
\text { Clark (2001), Plakoyiannaki and } \\
\text { Zotos (2009), White, Parsons and } \\
\text { Ceylan (2014), Lindenmeier (2008), } \\
\text { Aduloju, Odugbesan, and Oke } \\
\text { (2009), Mogaji and Danbury (2017), } \\
\text { Korkeamaki, Puttonen \& Smythe } \\
\text { (2007), Porter (1987), Hsu and Ho } \\
\text { (1988). }\end{array}$ \\
\hline
\end{tabular}


Devi and Joseph (2017) demonstrated that for the mutual fund information print media is most important. Sallam (2011) found that in a newspaper advertisement, the motivators for the reader are the picture(s) and information about the product which are there in the newspapers. Olbrich and Schultz (2014) discussed that print advertisement does not affect search engine advertisements.

Ekerdt and Clark (2001) focused on the print advertisement that motivated the investors towards retirement planning and investors a lot of attention to proactive males. Women equally play an important role in financial planning. Plakoyiannaki and Zotos (2008) found that print advertisements the sales can be increased by showing the advertisements which present the women entrepreneurs.

Mogaji and Danbury (2017) found that in print advertisements, the audience gave importance to the images that were used by the bank to convey their messages. Korkeamaki et al. (2007) demonstrated that for high performing mutual funds advertisement in the newspaper is very effective and target the large investors. Porter (1987) opined that the insurance policy advertised in the newspaper is poorly written which creates the expectation among the readers but does not attract any reader to buy it. Hsu and Ho (1988) found that bank advertisements in a newspaper generally focus on the "types and quality of services offered, geographic coverage in terms of the number of offices, as well as international experience, and company strength defined in terms of financial and/or technical".

Aduloju (2009) suggested increasing the sale of insurance products in every possible market it is very important to target them with a careful blend of print and electronic. Further, White (2014) suggested that in today's scenario success of media cannot be individual but it can be received by combining the offline and online media resources. The important parameter that attracts an audience is creativity in print advertisements. Yu (2007) found that creativity in print advertisements in the form of visuals and textual headings affects the perception of the audience.

\subsection{Internet Advertisements}

Birch (1996) found that banking and financial services will be restructured by the E-cash and the Internet in the coming next decade. The Internet is an effective means to communicate by employing videos, presentations, graphs, demonstrations, etc at a minimal cost. Debreceny et al. (2002) opined that the internet offers easy access, faster, flexible, and has more benefits as compared to newspapers, journals or other printing media. Due to the benefits of the internet is widely and attracted many corporate towards themselves (Ettredge et al., 2002). The Internet builds a strong relationship as the stakeholders get all the necessary information required for financial decision making (Sriram and Laksmana, 2006). Petravick and Gillet (1996) found that for the faster spreading of the information internet is considered an effective source.

Rao (2000) found that internet advertisements and promotions are good for computer software, financial services, insurance, travel, books, music, gifts, etc.

Internet banking is for both banks and customers, easily view their accounts, marketing and communication activities and can attract new customers (De Young et al., 2007). Bradley and Stewart (2002) found many banking services such as loan application, account opening; account balance inquiry can be done via the internet. The internet is affected by some of the limitations which include "information overload, poor website design, and advertising, ambiguous user preference, and competence" (Lodhia, 2004).

Table 3 summarized the various reviews are done on the topic of internet advertisement, advertisement effectiveness by the internet, the need for digital marketing, advantages of using online advertisements and so on.

Table 3: Review on the "Internet" used as media for the financial service advertisement

\begin{tabular}{|c|c|}
\hline Constructs & Researchers \& Year \\
\hline Internet media & $\begin{array}{l}\text { Arussi, Selamat,and Hanefah } \\
\text { (2009), Hojjati, Nikghadam and } \\
\text { Reza, (2013), Birch and Young } \\
\text { (1997), Boudreau and Watson } \\
\text { (2006), Zhang, Liu, Xinhui and } \\
\text { Zhu (2018), Barnatt (1998), } \\
\text { Mathur, Knowles and Gleason } \\
\text { (1998), Dolinsek, Tominc, and } \\
\text { Skerbinjek (2014), Chang, Rizal, } \\
\text { and Amin, (2013), Callaway } \\
\text { (2011), Polasik and Wisniewski } \\
\text { (2008), Flavian, Eduardo and } \\
\text { Guinaliu (2008) }\end{array}$ \\
\hline
\end{tabular}

Forman (2002) explored the factors that affect the firm's decision to adopt internet technologies and commercialization of the internet. The important factors are the likelihood of internet adoption and the lower cost of such advanced technology. The investors are looking for valuable information on the financial sector which reduces information asymmetry. Also, companies are looking for looking by which they can disseminate the information to the customers the best available option in the Internet Technology (Arussi et al., 2009). Polasik and Wisniewski (2008) found that more techno-savvy customers are more interested to open the online banking account.

Lee et al. (2011) suggested that the internet or weblogs can be used as future media for the promotion and presentation of financial products and services. Hindi and Rich (2010) opined that investors mostly used the internet as an information source that provides financial statements, a firm's performance, and governance information. Barnatt (1998) found that in financial services all the middlemen such as financial advisors could be replaced by the internet as it provides all the necessary and updated information, lower cost and more benefits to the customers.

Tatjana et al. (2014) found that internet financial reporting is done by every joint and large-scale company due to the reason that they will acquire new foreign investors. Boudreau and Watson (2006) found that the corporations should align the corporate goals with the web advertisements so that it will reach the maximum customers. One of the important modes of internet advertisement is e-mail. E-mail is the most successful form of personal and corporate communication which improves the brand image and has marketing success (Tezinde et al., 2002). 
The effectiveness of the email depends upon its type (i.e. permission-based e-mails or spamming) and it equally influences consumer acceptance towards the email (Chang, 2013). Polasik and Wisniewski (2008) found that security is very necessary for online banking. There are probable risks that are attached to the internet to use a banking website i.e. the conduct of financial transactions (Jayawardhena and Foley, 2000). Marquez (2000) demonstrated the reason that people hesitate to use internet banking websites due to lack of trust on the internet, security and less knowledge.

Janda et al. (2002) highlighted the importance of perceived security in internet transactions.

\subsection{Comparison of various media: The main effects of media on advertising effectiveness}

Recent researches focused and analyzed the differences between print media and online advertisement. Print media allows the audience to shortlist, pay attention, to the available cues and information for the different available products. Schönbach et al. (2005) found that newspapers provide awareness about public issues than online newspapers. Boczkowski (2004) discussed that print media have different policies as compared to online media. The biggest advantage of internet media is the ready news and easy availability of productive news (Hoffman, 2006). The most important parameter which differentiates the internet and the print media is interactivity (Nysveen and Breivik, 2005). The interactivity is defined as the relationship of the user with the advertisement.

Whereas, Sterne (1999) discussed that the internet is also attaining the customer's attention as compared to print media. Though is a lot of difference between the traditional print campaign and the online campaigns they appear to be similar in terms of content. Various researchers such as Faison (1980); Katz et al. (1973) and Schönbach et al. (2005) found that an educated audience is more inclined towards the usage of print media, while the less educated audience is more inclined towards the broadcast media. Therefore, the main highlights are the internet advertisement has more attention of the users, the opportunity to process the available information fruitfully to apply that information in the further future purchases (Nysveen and Breivik, 2005). As a result, the internet offers more additional benefits as compared to the print media advertisement. Based on the different viewpoint given by the various researchers, the following hypothesis has been formulated:

H1: Internet advertisements are more effective than the newspaper (print advertisements) or television, whereas newspaper (print advertisements) is more effective than internet advertisements.

\subsection{Effects of Appeal on advertising effectiveness}

"An emotional response that arises from the emotional condition and matches up with the other's emotional state or situation" (Escalas \& Stern, 2003). Related studies in the field of advertisement identified the role of emotional appeal in the effectiveness of the message (Xie \& Osmonbekov, 2004). Emotions of a person affect information processing, responses towards appeals, reactions, attention, and purchase decisions (Bagozzi et al., 1999; Gardner, 1985).
Geuens and De Pelsmacker (1999) examined the "emotions" and "intensity" of different emotional and non-emotional advertising appeals. Xie (2004) found that positive emotional appeals are superior in creating a center of attention of the consumers as compared to the advertisements with no emotional appeals. Alhabash et al. (2013) found that emotional appeal with entertainment in the advertisement affects the attitude toward advertising.

A rational appeal involves detailed information, logic, arguments (Zhang et al., 2014), dull and too informative (Belch and Belch, 2012) and factual information characterized by objectivity (Stafford and Day, 1995). The rational appeal focused on the benefits of the products or service which the customer expects from the final product purchase (Kotler, 1997). Rational appeal encourages the customers to purchase the product based on the rational decision based on the benefits of the product or service (Arens, 2006). Aaker and Norris (1982) found that rational appeals develop a strong advertising attitude as compared to emotional appeal. Ray and Batra (1983) found that rational appeals are more prominent in attracting the customer's attention as rational identification comes before the emotional ones. Clow and Baack (2012) found that rational appeals are better for high involvement products as compared to low involvement products. Whereas, Albers-Miller and Stafford (1999) concluded that in financial service advertising rational appeals are more effective and in travel services, emotional appeals are more effective.

In summary, the advertisement contains the emotional, rational, information and creative aspects that are embedded and exposed to attain the attention of the viewers (Lee \& Hong, 2016).

H2: Rational appeals are more effective for internet advertisements as compared to newspaper advertisements.

H3: Rational appeals are more effective for newspaper advertisements than for internet advertisements.

Advertisement evokes associations which are used for the sales evaluation in addition to the brand image and the delivered message. Drèze \& Zufryden (1997) found that internet advertisement offers a combination of sound, text, video, animation, and pictures. This is converted into the synergy effect which makes the advertisement effective medium for distribution of information with an emotional appeal (Gallagher, 2001). Coyle and Thorson (2001) concluded that online advertising has a high degree of interactivity and effective in conveying the intended message. In the print advertisement, the reader has control over the content (Lee, 2000) and in the online advertisement, they have control over the clicks and scrolls (Dahlén, 2002). Tiwana (1998) concluded that online advertisements are rational as they provide the information required by customers. Toncar and Munch (2001) found that in low involvement products print emotional appeals are more effective. Gallagher et al. (2001) found that there is no difference between the print advertisement and online advertisement. Based on the above discussion, the following hypothesis is proposed.

H4: Emotional appeals are more effective for internet advertisements as compared to newspaper advertisements

H5: Emotional appeals are more effective for internet advertisements than for newspaper advertisements 


\section{RESEARCH METHODOLOGY}

The study investigated the three different media i.e. print, electronic and online utilized by the financial sector. The study focuses on the two types of appeals i.e. rational and emotional appeal used for the different types of financial products such as mutual funds, insurance, and banking products. The items in the scale were adapted and modified from the various researchers on the topic of the financial service advertisements. A non disguised questionnaire was framed and distributed to 527 respondents using the convenience sampling technique.

The respondents belong to major cities of Punjab (northern India) such as Amritsar, Jalandhar, Ludhiana and Tricity city i.e. Chandigarh.

The respondents were shown the financial service advertisement $(6=$ mutual funds, $6=$ insurance, and 6=banking products) and asked to mark the question related to the shown advertisements. The first section of the questionnaire included questions covering the six constructs (i.e. Attitude to product/service provider,
Attitude to the advertisement, Trustable and Product Planning). The second section was about respondents' demographics (i.e. gender, age, education, occupation, and monthly income). They had also asked to rank the various media, Patterns of Time spent on each media and Perceived Media Advertising Usefulness, Time spent on each media and Usefulness of media. Incomplete responses in any form were discarded and final sample size shrinks to 481 respondents with a response rate of $91.2 \%$

\section{DATA ANALYSIS}

\subsection{Rank of various media}

The respondents were given the five media out of which they have to denote the rank starting from $1=$ most preferred media to $5=$ least preferred media. Five media option includes television, newspaper, internet, radio, and mobile. The responses are recorded into SPSS sheet and afterward, Garrett Ranking Technique has been used in order to analyze the required results.

Table 4: Ranking of various media

\begin{tabular}{|c|c|c|c|c|c|c|c|c|}
\hline Rank & 1 & 2 & 3 & 4 & 5 & \multirow[t]{2}{*}{ Total } & \multirow[t]{2}{*}{ Total/481 } & \multirow[t]{2}{*}{ Rank } \\
\hline Score & 82 & 70 & 63 & 58 & 52 & & & \\
\hline & 131 & 112 & 82 & 99 & 57 & \multirow{2}{*}{32454} & \multirow[b]{2}{*}{67.5} & \multirow{2}{*}{2} \\
\hline Television & 10742 & 7840 & 5166 & 5742 & 2964 & & & \\
\hline \multirow[t]{2}{*}{ Internet } & 197 & 102 & 82 & 75 & 25 & \multirow{2}{*}{34110} & \multirow{2}{*}{70.9} & \multirow[b]{2}{*}{1} \\
\hline & 16154 & 7140 & 5166 & 4350 & 1300 & & & \\
\hline \multirow[t]{2}{*}{ Newspaper } & 79 & 125 & 105 & 83 & 89 & \multirow{2}{*}{31285} & \multirow{2}{*}{65.0} & \multirow{2}{*}{3} \\
\hline & 6478 & 8750 & 6615 & 4814 & 4628 & & & \\
\hline \multirow[t]{2}{*}{ Radio } & 36 & 63 & 134 & 140 & 108 & \multirow{2}{*}{29540} & \multirow{2}{*}{61.4} & \multirow{2}{*}{4} \\
\hline & 2952 & 4410 & 8442 & 8120 & 5616 & & & \\
\hline \multirow[t]{2}{*}{ Mobile } & 39 & 74 & 80 & 91 & 197 & \multirow{2}{*}{28940} & \multirow{2}{*}{60.2} & \multirow[b]{2}{*}{5} \\
\hline & 3198 & 5180 & 5040 & 5278 & 10244 & & & \\
\hline
\end{tabular}

Table 4 highlights the ranking of the various media used for the financial service advertisement. The results illustrate that internet media is given the first rank among the five given options. This support that today's world is more dependent upon the internet media and advertisement field is no exception to it. The results prove that financial advertisements are liked on the internet as comparison can be easily done. This demonstrates that respondents felt that financial service advertisement is more likable on the Internet as compared to the other media. The second rank is given to the television followed by the newspaper. The fourth rank is given to the radio and the fifth rank is given to mobile advertisements. This explains that respondents less prefer the advertisements on these two media as they felt uncomfortable and found less helpful for these two types of media.

\subsection{Reliability and validity}

The internal validity of the scale was examined by Composite Reliability and Average Variance Extracted. The values of all the latent variables of the present scale are greater than or equal to the acceptable limit i.e. 0.7 (Carmines and Zeller, 1988) and 0.5 (Bagozzi and Yi, 1988; Fornell and Larcker, 1981) respectively. Thus the reliability of all the six factors has been proved in this study.

Table 5: Reliability and validity

\begin{tabular}{|c|c|c|c|c|}
\hline \multirow{2}{*}{ Constructs } & $\begin{array}{c}\text { Standardized } \\
\text { Estimates }\end{array}$ & p-value & AVE & CR \\
\hline \multirow{3}{*}{$\begin{array}{c}\text { Attitude towards product/service } \\
\text { provider }\end{array}$} & 0.72 & $*$ & & \\
\cline { 2 - 3 } & 0.593 & $*$ & \multirow{2}{*}{0.739} & \multirow{2}{*}{0.724} \\
\cline { 2 - 3 } & 0.732 & $*$ & \\
\cline { 2 - 3 } & 0.913 & $*$ & & \\
\hline
\end{tabular}


Is Financial Advertisement Effectiveness is Dependent on the Type of Media? A Case of Print, Electronic and Online Media

\begin{tabular}{|c|c|c|c|c|}
\hline \multirow{4}{*}{ Attitude towards advertisement } & 0.79 & $*$ & \multirow{4}{*}{0.704} & \multirow{4}{*}{0.876} \\
\hline & 0.808 & $*$ & & \\
\hline & 0.852 & $*$ & & \\
\hline & 0.801 & $*$ & & \\
\hline \multirow{3}{*}{ Trustable } & 0.771 & $*$ & \multirow{3}{*}{0.654} & \multirow{3}{*}{0.85} \\
\hline & 0.809 & * & & \\
\hline & 0.83 & * & & \\
\hline \multirow{2}{*}{ Product Planning } & 0.788 & $*$ & \multirow{2}{*}{0.655} & \multirow{2}{*}{0.85} \\
\hline & 0.694 & * & & \\
\hline \multirow{4}{*}{ Emotional appeal } & 0.608 & * & \multirow{4}{*}{0.66} & \multirow{4}{*}{0.712} \\
\hline & 0.712 & $*$ & & \\
\hline & 0.666 & * & & \\
\hline & 0.702 & * & & \\
\hline \multirow{3}{*}{ Rational appeal } & 0.698 & * & \multirow{3}{*}{0.512} & \multirow{3}{*}{0.73} \\
\hline & 0.666 & $*$ & & \\
\hline & 0.735 & * & & \\
\hline
\end{tabular}

\subsection{Confirmatory Factor Analysis}

The data was analyzed using the factor analysis to find the most important factors that play an important role in the preference for the media. The exploratory factor analysis extracted four factors out of twenty variables which explain the $61.2 \%$ of the total variance. The four factors consist of a total of 12 items. The important extracted factors are attitude to product/service provider, attitude to the advertisement, trustable and product planning. On the extracted factors, confirmatory factor analysis had been applied to check the properties of the dependent measures.

CFI and GFI are above the recommended level of fit (CFI $=0.928$, GFI $=0.902$ ), whereas RMSEA is also satisfactory (RMSEA $=0.12$ ). The values of the indices prove that model with eleven observables was acceptable. The analysis reveals that all constructs possess satisfactory construct reliability i.e. average variance extracted above 0.5 (Bagozzi \& Yi, 1988). Furthermore, convergent and discriminant validity was found acceptable and lie in the limit as suggested by Anderson \& Gerbing (1988) and Fornell \&Larcker (1981).

\section{Table 6: Model fit Indices}

\begin{tabular}{|l|l|c|}
\hline \multicolumn{1}{|c|}{ Fit indices } & \multicolumn{1}{c|}{ Recommended } & Model value(s) \\
\hline Chi-square & & 114.154 \\
\hline Goodness of Fit Index (GFI) & (Joreskog and Sorbom 1988) $\geq 0.90$ & 0.902 \\
\hline Adjusted Goodness of fit Index (AGFI) & (Joreskog and Sorbom 1988) $\geq 0.80$ & 0.876 \\
\hline Comparative Fit Index (CFI) & (Bentler 1990) $\geq 0.90$ & .928 \\
\hline Root means square of approximate (RMSEA) & (Hu and Bentler 1990) $\leq 0.05$ & .012 \\
\hline Tucker-Lewis index (TLI) & (Bentler 1990) $\geq 0.90$ & .929 \\
\hline Normed fit index (NFI) & (Bentler 1990) $\geq 0.60$ & .946 \\
\hline Incremental fit index (IFI) & (Bentler 1990) $\geq 0.90$ & .949 \\
\hline
\end{tabular}

\subsection{Manipulation check}

From the model, seven items were used to examine the effect of ad stimuli of the message appeal. The factor analysis extracted the two factors: four items on the first factor and three statements on the second factor. The first factor named as emotional appeal (alpha= 0.81) and second factor named as rational appeal (alpha=0.84). The items are presented in the appendix.

Table 7: Mean Values

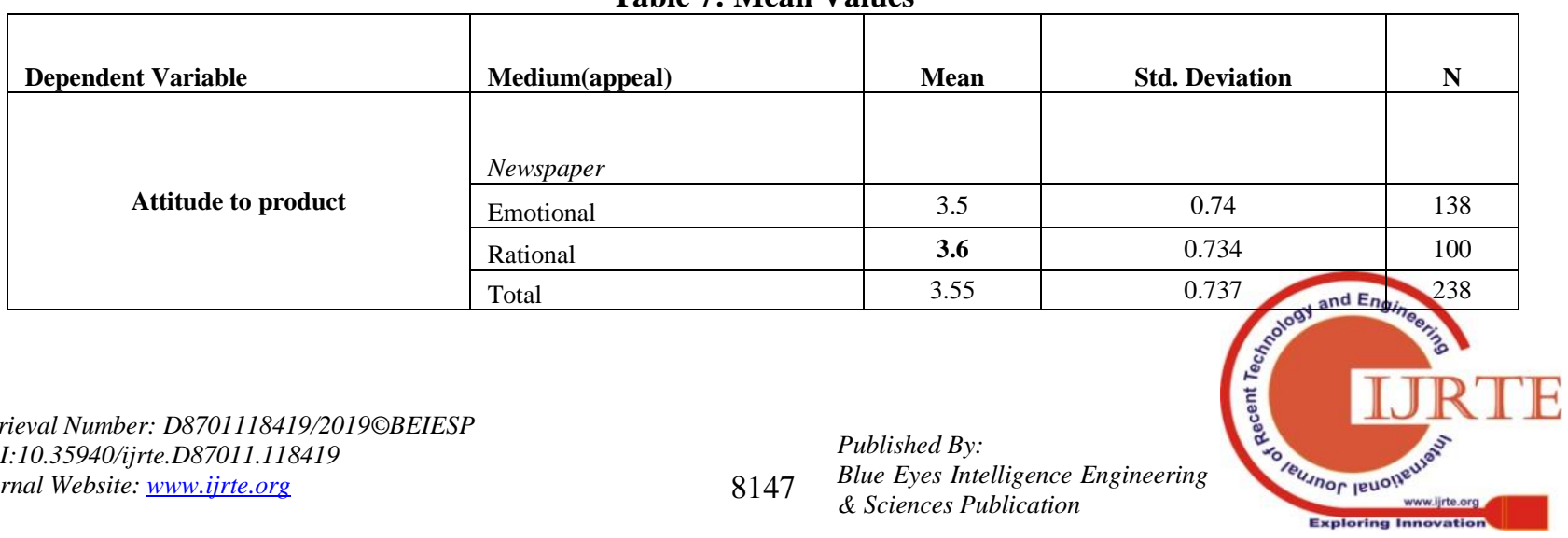

\subsection{Manova Analysis}

The effectiveness of the advertisements presented in the three media is based on comparisons of mean values of the dependent variables: attitude to advertised product, attitude to advertisement, Trustable and Product Planning. The mean values are presented in Table 7 


\begin{tabular}{|l|c|c|c|} 
Television & & & \\
\hline Emotional & 3.33 & 0.84 & 96 \\
\hline Rational & 3.58 & 0.83 & 70 \\
\hline Total & 3.455 & 0.835 & 166 \\
\hline
\end{tabular}

Attitude to ad

Trustable

Product planning

\begin{tabular}{|c|c|c|c|}
\hline \multicolumn{4}{|l|}{ Internet } \\
\hline Emotional & 3.53 & 0.784 & 50 \\
\hline Rational & 3.6 & 0.686 & 27 \\
\hline Total & 3.565 & 0.735 & 77 \\
\hline Emotional & 3.45 & 0.8 & 284.0 \\
\hline Rational & 3.59 & 0.8 & 197.0 \\
\hline Total & 3.52 & 0.8 & 481.0 \\
\hline \multicolumn{4}{|l|}{ Newspaper } \\
\hline Emotional & 3.7 & 0.84 & 138 \\
\hline Rational & 3.9 & 0.8 & 100 \\
\hline Total & 3.8 & 0.82 & 238 \\
\hline \multicolumn{4}{|l|}{ Television } \\
\hline Emotional & 3.75 & 0.81 & 96 \\
\hline Rational & 3.12 & 0.89 & 70 \\
\hline Total & 3.435 & 0.85 & 166 \\
\hline \multicolumn{4}{|l|}{ Internet } \\
\hline Emotional & 4.12 & 1.22 & 50 \\
\hline Rational & 4.09 & 1.15 & 27 \\
\hline Total & 4.105 & 1.185 & 77 \\
\hline Emotional & 3.86 & 0.96 & 284.0 \\
\hline Rational & 3.70 & 0.95 & 197.0 \\
\hline Total & 3.78 & 0.95 & 481.0 \\
\hline \multicolumn{4}{|l|}{ Newspaper } \\
\hline Emotional & 3.55 & 1.11 & 138 \\
\hline Rational & 4.11 & 1.02 & 100 \\
\hline Total & 3.83 & 1.065 & 238 \\
\hline \multicolumn{4}{|l|}{ Television } \\
\hline Emotional & 3.99 & 0.81 & 96 \\
\hline Rational & 3.12 & 0.89 & 70 \\
\hline Total & 3.555 & 0.85 & 166 \\
\hline \multicolumn{4}{|l|}{ Internet } \\
\hline Emotional & 3.97 & 0.98 & 50 \\
\hline Rational & 3.77 & 0.89 & 27 \\
\hline Total & 3.87 & 0.935 & 77 \\
\hline Emotional & 3.84 & 0.97 & 284.0 \\
\hline Rational & 3.67 & 0.93 & 197.0 \\
\hline Total & 3.75 & 0.95 & 481.0 \\
\hline \multicolumn{4}{|l|}{ Newspaper } \\
\hline Emotional & 3.66 & 1.22 & 138 \\
\hline Rational & 3.87 & 0.99 & 100 \\
\hline Total & 3.765 & 1.105 & 238 \\
\hline \multicolumn{4}{|l|}{ Television } \\
\hline Emotional & 4.15 & 0.87 & 96 \\
\hline Rational & 4.32 & 0.81 & 70 \\
\hline Total & 4.235 & 0.84 & 166 \\
\hline \multicolumn{4}{|l|}{ Internet } \\
\hline Emotional & 4.02 & 1.21 & 50 \\
\hline Rational & 4.12 & 1.11 & 27 \\
\hline Total & 4.07 & 1.16 & 77 \\
\hline
\end{tabular}


Is Financial Advertisement Effectiveness is Dependent on the Type of Media? A Case of Print, Electronic and Online Media

\begin{tabular}{|l|l|l|l|} 
Emotional & 3.94 & 1.10 & 284.0 \\
\hline Rational & 4.10 & 0.97 & 197.0 \\
\hline Total & 4.02 & 1.04 & 481.0 \\
\hline
\end{tabular}

advertisement medium (Internet, newspaper, and television) as independent variables (Model 1). Afterward, medium and appeal were taken as independent variables against the same dependent variables and MANOVA test was applied (Model

MANOVA test was applied to test the effect of advertising media. In this attitude towards product, attitude towards an advertisement, product planning and trustable were taken as dependent variables and the

Table 8: MANOVA results

\begin{tabular}{|c|c|c|c|c|c|c|c|c|}
\hline & \multicolumn{2}{|c|}{ Attitude to product } & \multicolumn{2}{|c|}{ Attitude to ad } & \multicolumn{2}{|c|}{ Product Planning } & \multicolumn{2}{|c|}{ Trustable } \\
\hline & $\mathrm{F}$ & $\mathrm{p}$ & $\mathrm{F}$ & $\mathrm{p}$ & $\mathrm{F}$ & $\mathrm{P}$ & $\mathrm{F}$ & $\mathrm{P}$ \\
\hline \multicolumn{9}{|l|}{ Model 1} \\
\hline * Medium & 1.581 & .208 & 3.961 & .020 & .561 & .571 & .161 & .851 \\
\hline \multicolumn{9}{|l|}{ Model 2} \\
\hline * Medium & 1.489 & 0.201 & 3.561 & 0.014 & 0.45 & 0.51 & 0.15 & 0.74 \\
\hline *Appeal & 1.320 & .043 & 1.634 & .001 & 1.284 & .061 & 1.813 & .000 \\
\hline * Medium $\times$ Appeal & .814 & .872 & .957 & .589 & .628 & .995 & .930 & .651 \\
\hline
\end{tabular}

Model 1 in Table 8 reveals that the medium does affect advertising effectiveness. From Table 7 , it can be predicted that the mean value of attitude towards the advertised product is highest for the internet and newspaper advertisement. According to the results from a posthoc test (Tukey HSD test), the advertisement presented on the internet $(\mathrm{p}=.041)$ and newspaper $(\mathrm{p}=.041)$ was significantly more effective than the television advertisement $(p=0.889)$. However, there were no differences between the believable effects of the advertisements presented on television.

For attitude towards the product, the results predict that the respondents felt that none of the media is significantly affecting their views towards the advertised product. No significant difference between all the three mediums. Therefore, their views towards the advertised product on any medium do not affect the respondents. Thus, the results do not support Hypothesis 1 as internet advertisements are more effective than newspaper advertisements.

In model 2, the advertisement appeal had been added along with the medium to test the combined effect of medium \& advertisement appeal for the four dependent variables. The results reveal the importance of message appeal (Rational and emotional appeal) as a factor in the advertisement effectiveness. The p-value shows that appeal has a significant relationship with the attitude to the product, attitude towards advertisement and trustable and non significant relation with the product planning. However, the interaction effects between the advertisement appeal and medium have an insignificant effect, which interpreted that none of the media is more or less effective for distribution of advertisements with various appeals. Hence, Hypotheses 2, 3,4 and 5 do not receive support.
Therefore, it is showed from the above analysis that effect of medium on advertising effectiveness, suggests that relative quality of the advertisements contribute towards the media effects as proved from model 1 and 2. However, the advertisement appeals are not affected by

the type of medium used for the advertisement. The advertisements for the three financial products (mutual funds, insurance, and banking products) for the three

different medium (such as the internet, newspaper, and television) were used in this study to assess the effect of medium and advertisement appeals on the advertisement effectiveness. Further, product type was included with the main effect analysis of medium, appeal, trustable; product planning does not alter the conclusion cited above.

\section{DISCUSSION AND CONCLUSION}

The results reveal that the internet and the newspaper provide the receiver the more detailed, trustable, useful information concerning the information processing as compared with the information received from the television commercials. On the internet and the newspaper, the information is much elaborated and controlled by the viewer as compared with the television. Therefore, financial products advertisements which are broadcasted on the internet and the newspaper are more effective in comparison to the broadcasted on the television.

These results are consistent with the ranking results, where the respondents gave the first rank to the newspaper and second rank to the internet afterward the third rank to the television. Therefore, it proves that newspapers and the internet appear to be more effective as compared to television as a medium for financial service advertisements. 
Television advertisements governed by the visuals, sounds, slogans, music provide the television more power as compared to print media. Whereas, the internet media combines with the benefits of the television media provides more in-depth information as required by the receiver (Dijkstra, 2005). But in case of the high involvement products (financial products) the television is not effective as newspaper and internet provides the user to process and sequence the information at its discretion (Jacoby et al., 1983). Besides, the newspaper and the internet provide the user to retain and read the message as per its convenience which further depends upon the interest of the receiver (Buchholz and Smith, 1991).

Whereas, our finding is consistent with the Sundar et al. (1998) which states that memory performance is better than the internet. The probable reason is the paper v/s computer as in the case of the printed newspaper the reader processes the complete ad and no need to be scrolled down.

\section{LIMITATIONS}

To some of the variables might be the risk that is associated with the internet, authenticity, and usefulness of internet advertisements. The investigation of the internet advertisement is limited as it ignores the types of internet advertisement, cognitive effects and the personalized messages used by the financial companies. Thus, the respondents fail to differentiate which parameters they have to access financial ads. Based on these arguments, concerning controlled information, personalization opportunities, audio and video presentation on the internet, it can be a more effective medium as compared to the print medium. These opportunities invite that the internet is a very powerful engine and media in the upcoming future which proves to be more successful as compared to traditional media.

\section{FUTURE DIRECTIONS}

There are some of the aspects which need to be discussed in the future research. First, the comparison of the three media, the rank order of the three media, and the control information have not employed earlier. The main benefit is it identifies and clears the effectiveness of each media very minutely. This would also lead to the kind of appeal that will be more effective on each media. The results of the present study show the importance of the advertisement appeal and media selected for the type of financial advertisement.

\section{REFERENCES}

1. Aduloju, S.A. Odugbesan, A.O. Oke, S.A. (2009). The effects of advertising media on sales of insurance products: a developingcountry case, The Journal of Risk Finance, 10(3), 210 - 227.

2. Albers-Miller, N. D. and Stafford, M. R.(1999). International services advertising: An examination of variation in appeal use for experiential and utilitarian services, Journal of Services Marketing, 13(4/5), 390-406.

3. Alhabash, S., \& McAlister, A. R. (2014). Redefining virality in less broad strokes: predicting viral behavioral intentions from

motivations and uses of Facebook and Twitter, New Media \& Society, 123.

4. Arens, W.F., 2006. Contemporary advertising. 10th Edn., New York: McGraw-Hill Irwin.

5. Arussi, Ali Saleh Al. Selamat, Mohamad Hisyam. and Hanefah, Mustafa Mohd. (2009). Determinants of financial and environmental disclosures through the internet by Malaysian companies, Asian Review of Accounting, 17(1), 59 - 76 .

6. Bagozzi, Richard P., Mahesh Gopinath, and Prashanth U. Nyer (1999) The Role of Emotions in Marketing, Journal of the Academy of Marketing Science, 27 (2), 184-206.

7. Barnatt, Christopher.(1998). Virtual communities and financial services on-line business potentials and strategic choice, International Journal of Bank Marketing, 16(4), 161-169.

8. Belch, G. E. \& Belch, M. A. (2012). Advertising and Promotion, an Integrated Marketing Communication Perspective, 9th Ed, McGraw-Hill. Singapore, 290- 294.

9. Boudreau, Marie-Claude. and Watson, Richard T. (2006). Internet advertising strategy Alignment, Internet Research, 16(1), 23-37.

10. Buchholz, LM. \& Smith, RE.(1991). The role of consumer involvement in determining cognitive response to broadcast advertising. Journal of Advertising, 20, $4-17$

11. Callaway, Stephen K. (2011). Internet banking and performance: The relationship of web site traffic rank and bank performance, American Journal of Business, 26(1), 12-25.

12. Clow, K. E. \& Baack, D. (2012). Integrated Advertising, Promotion, and Marketing Communications, 5th ed. Pearson Global Edition. Edinburgh Gate. $159-178$.

13. Clow, K.E., Tripp, C. and Kenny, J.T. (1996). The importance of service quality determinants in advertising a professional service: an exploratory study, The Journal of Services Marketing, 10(2), 57-70.

14. Coyle, J.R. and Thorson, E. (2001). The effects of progressive levels of interactivity and vividness in Web marketing sites, Journal of Advertising, 30(3), 65-77.

15. Cutler, B.D. and Javalgi, R.G. (1993). Analysis of print ad features: services versus products, Journal of Advertising Research, March/April, pp. 62-9.

16. Dahlén, M. (2002). Learning the Web: Internet user experience and response to Web marketing in Sweden. Journal of Interactive Advertising, 3(1).

17. Dash, M. and Belgaonkar, P. (2012). Comparative Effectiveness of Radio, Print and Web Advertising. Available at SSRN: http://ssrn.com/abstract=2190083.

18. Debreceny, R., Gray, G.L. and Rahman, A. (2002). The determinants of internet financial reporting, Journal of Accounting and Public Policy, 21(4/5), 371-94.

19. Devi, N.Nandhini. Joseph, Dr.A. Velanganni. (2017). Determinants of Mutual Fund Selection by Individual investors in Coimbatore city", 19(9), 52-59.

20. Dolinšek, Tatjana. Tominc, Polona. and Skerbinjek, Andreja Lutar. (2014). The determinants of internet financial reporting in Slovenia, Online Information Review, 38(7), 842 - 860.

21. Drèze, X. \& Zufryden, F. (1997). Testing website design and promotional content. Journal of Advertising Research, 77-91.

22. Ekerdt, David J. Clark, Evelyn (2001). Selling retirement in financial planning advertisements, Journal of Aging Studies, 15, 55-68.

23. Ettredge, M., Richardson, V.J. and Scholz, S. (2002). Timely financial reporting at corporate web sites?, Communications of the ACM, 45(6), 6771.

24. Flavián, Carlos. Torres, Eduardo. and Guinalíu, Miguel. (2004). Corporate image measurement: A further problem for the tangibilization of Internet banking services, International Journal of Bank Marketing, 22(5), 366-384

25. Forman, C. (2002). The corporate digital divide: determinants of internet adoption, Kellogg school of management northwestern university, available at: http://citeseerx.ist.psu.edu/ viewdoc/download.

26. Gallagher, K., Parsons, J. and Foster, K.D. (2001b). A tale of two studies: replicating advertising effectiveness and content evaluation in print and on the Web, Journal of Advertising Research, 41(4), 71-82.

27. Gardner, Meryl Paula (1985). Mood States and Consumer Behavior: A Critical Review, Journal of Consumer Research, 12, 281-300.

28. Geuens, Maggie D. and Patrick De Pelsmacker (1999). Affect Intensity Revisited: Individual Differences and the Communication Effects of Emotional Stimuli, Psychology and Marketing, 16 (3), 195-209.

29. Hoffman, Lindsay H. (2006). Is Internet Content Different After All? A Content Analysis Of Mobilizing Information In Online And Print Newspapers, J \& Mc Quarterly, 3(1), 58-76.

Published By: 
30. Hojjati, Sanaz Nikghadam. Rabi, Ali Reza .(2013). Effects of Iranian online behavior on the acceptance of internet banking, Journal of Asia Business Studies, 7(2),123-139.

31. Howcroft, Barry. Hamilton, Robert. and Hewer, Paul. (2007). Customer involvement and interaction in retail banking: an examination of risk and confidence in the purchase of financial products, Journal of Services Marketing, 21(7),481-491.

32. Hsu, Dan-lin and Ho, Suk-ching. (1988). Advertising by Banks in Hong Kong: A Content Analysis, International Journal of Bank Marketing, 6(2), $62-67$.

33. Jacoby J, Hoyer WD, Zimmer MR. (1983). To read, view, or listen? A cross-media comparison of comprehension. Current issues and research in advertising. Ann Arbor (MI): University of Michigan, 201- 217.

34. James, W.L. and Kover, A.J. (1992). Do overall attitudes toward advertising affect involvement with specific advertisements?, Journal of Advertising Research, 32(5), 78-83.

35. Janda, S., Trocchia, P. and Gwinner, K. (2002). Consumer perceptions of internet retail service quality, International Journal of Service Industry Management, 13(5), 412-31.

36. Jayawardhena, Chanaka. And Foley, Paul. (2000). Changes in the banking sector - the case of Internet banking in the UK, Internet Research: Electronic Networking Applications and Policy, 10(1), 19-30.

37. Karniouchina, Ekaterina V., William L. Moore, and Keving J. Cooney. (2009). Impact of Mad Money Stock Recommendations: Merging Financial and Marketing Perspectives, Journal of Marketing, 73 (6), 244-266.

38. Kotler, P., 1997. Marketing management: Analysis, planning, implementation and control. 9th Edn., New Jersey: Prentice-Hall.

39. Lee, Jieun. \& Hong, Ilyoo B. (2016). Predicting positive user responses to social media advertising: The roles of emotional appeal, informativeness, and creativity, International Journal of Information Management, 36 (2016) 360-373.

40. Lee, Taejun (David) .Chung, Wonjun. Taylor, Ronald E. (2011). A strategic response to the financial crisis: an empirical analysis of financial services advertising before and during the financial crisis, Journal of Services Marketing, 25(3), 50-164.

41. Lodhia, S.K. (2004). Corporate environmental reporting media: a case for the world wide web, Electronic Green Journals, 20, 10767975.

42. Luo, X. and Donthu, N. (2005). Assessing advertising media spending inefficiencies in generating sales, Journal of Business Research, 58(1), 28-36.

43. Marquez, A. (2000). Internet y la actividad bancaria, Papeles de Economi'a Españ ola, 84-85, 330-339.

44. Mathur, Lynette Knowles. Mathur, Ike. Gleason, Kimberly C. (1998). Services advertising and providing services on the Internet, Journal of Services Marketing, 12(5), 334-347.

45. Mittal, B. (1994). Public assessment of TV advertising: faint praise and harsh criticism, Journal of Advertising Research, 34(1), 35-54

46. Mogaji, Emmanuel and Danbury, Annie (2017). Making the brand appealing: advertising strategies and consumers' attitude towards UK retail bank brands, Journal of Product \& Brand Management.

47. Moore, S.E. (2004). Children and changing world of advertisements, Journal of Business Ethics, 52, 161-7.

48. Neza, Violeta. And Myftaraj, Ervin. (2016). The influence of advertising in insurance companies in Albania and consumer decision making process, Interdisplinary Journal of Research and Development, 3(1), 111-117.

49. Nysveen, Herbjørn. and Breivik, Einar (2005). The influence of media on advertising effectiveness A comparison of internet, posters and radio, International Journal of Market Research, 47(4), 383-405.

50. Olbrich, Rainer. and Schultz, Carsten D. (2014). Multichannel advertising: does print advertising affect search engine advertising?, European Journal of Marketing, 48(9/10), 1731-1756

51. Pablo J. Boczkowski(2004). Digitizing the News: Innovations in Online Newspapers Cambridge: The MIT Press.

52. Petravick, S. and Gillet, J. (1996). Financial reporting on the world wide web, Management Accounting, pp. 26-9.

53. Pieters, Rik G.M. and Tammo H.A. Bijmolt (1997). Consumer Memory for Television Advertising: A Field Study of Duration, Serial Position, and Competition Effects, Journal of Consumer Research, 23 (4), 362-72.

54. Polasik, Michal. And Wisniewski, Tomasz Piotr. (2009). Empirical analysis of internet banking adoption in Poland, International Journal of Bank Marketing, 27(1),32-52.

55. Ponsford, D. (2015).ABC circulation breakdown: 60 out of 442 titles grow sales. PressGazette. Retrieved December 29, 2016 2016, from http://www.pressgazette.co.uk/full-2015-mag-abcs-breakdowncosmopolitan-bucks-trend-ukmagazines- decline-average-4-cent/ Shenton.

56. Porter, James E. (1987). Truth in Technical Advertising: A Case Study, IEEE Transactions actions on professional communication, 30(3), 182 189

57. Rao, Siriginidi Subba. (2000). Internet service providers: an Indian scenario, Online Information Review, 24(4), 322-328.

58. Ray, M.L. and R. Batra, (1983). Emotion \& persusion in advertising: What we do \& don't know about affect. In: Bagozzi RP, Tybout AM (Eds.) Advances in Consumer Research, 6(1), 543-548.

59. Saha, Anita. Pal, Madhumangal. and Pal, Tapan K.(2007). Selection of programme slots of television channels for giving advertisement: A graph theoretic approach, Information Sciences, 177, 2480-2492.

60. Sallam, Methaq Ahmed Abdulmajid. (2011). The Impact of Source Credibility on Saudi Consumer's Attitude toward Print Advertisement: The Moderating Role of Brand Familiarity, International Journal of Marketing Studies, 3(4), 63-77.

61. Schönbach, K., Waal, E. de, and Lauf, E. (2005). Research note: Online and print newspaper. Their impact on the extent of the perceived public agenda. European Journal of Communication, 20(2), 245258.

62. Smit, E. (1999), Mass media advertising: Information or wallpaper?, Het Spinhuis, Amsterdam.

63. Soni, Mayank Jyotsna. (2017). Effects of varying involvement level within a television program on recall of cognitive versus affective advertisement, Journal of Consumer Marketing, 34(4), 338-348.

64. Sriram, R.S. and Laksmana, I. (2006). Corporate web site reports: some evidence on relevance and usefulness, Information Resources Management Journal, 19(3),1-28

65. Stafford, M. R., Stafford, T. F. and Day, E. (2002). A contingency approach: the effects of spokesperson type and service type on service advertising perceptions, Journal of Advertising, 31(2), 17-34.

66. Sundar SS, Narayan S, Obregon R, Uppal C.( 1998). Does web advertising work? Memory for print versus online media, Journal Mass Communication, 75, 822-35.

67. Taha, Ahmed E and Palmiter, Alan. (2011). Mutual Fund Performance Advertising: Inherently and Materially Misleading?, Wake Forest University.

68. Tan, S.J. and Chia, L. (2007). Are we measuring the same attitude? Understanding media ffects on attitude towards advertising, Marketing Theory, 7(4), 353-377.

69. Tezinde, T., Smith, B. and Murphy, J. (2002). Getting permission: exploring factors affecting permission marketing, Journal of Interactive Marketing, 16(4), 28-36.

70. Tiwana, A.B. (1998). Interdependency factors influencing WWW, Journa of Retailing and Consumer Services, 5(4), 245-53.

71. Toncar, M. and Munch, J. (2001). Consumer responses to tropes in advertising, Journal of Advertising, 30(1), 55-65.

72. Viswanathan, Madhubalan and Terry L. Childers. (1996). Processing of Numerical and Product Information, Journal of Consumer Psychology, 5 (4), 359-386.

73. Weinberger, M.G. and Brown, S.W. (1977). A difference in informationa influences: services vs goods, Journal of the Academy of Marketing Science, 5(4),389-402.

74. White, Elzbieta Lepkowska. Parsons, Amy. and Ceylan, Aylin. (2014) Cross promotion of web references in print ads: Are advertisers attempting to engage consumers?, Journal of Research in Interactive Marketing, 8 (4), 309-326.

75. Xie, Frank Tian. (2004). Emotional Appeal and Incentive Offering in Banner Advertisements, Journal of Interactive Advertising, 4(2).

76. Zhang ,Hongxia. Sun Fang Liu, Jin. \& Knight, John Gordon. (2014). Be rational or be emotional: advertising appeals, service types, and consumer responses, European Journal of Marketing, 48(11/12).

77. Zhang, Yun. Chen, Xiaogang. Liu, Xinhui. and Zhu, Nan. (2018) Exploring trust transfer between internet enterprises and their affiliated internet-only banks: An adoption study of internet-only banks in China, Chinese Management Studies, 1-24.

78. Zinkhan, George M. Johnson, Madeline. Zinkhan, F. Christian (1992) Differences Between Product and Services Television Commercials, Journal of Services Marketing, 6(3), 59 - 66. 


\section{Appendix: An Initial Pool of Statements of Media effectiveness}

\begin{tabular}{|c|c|c|}
\hline $\begin{array}{l}\text { Dimensions } \\
\text { (Source) }\end{array}$ & $\begin{array}{l}\text { Sr. } \\
\text { No }\end{array}$ & Statements \\
\hline \multirow{4}{*}{$\begin{array}{l}\text { Attitude towards product/service provider } \\
\text { (Mitchell \& Olson 1981) }\end{array}$} & 1 & In the advertisements we can easily access the infrastructure of the financial provider. \\
\hline & 2 & I became interested in the product after listening to/ seeing the advertisement. \\
\hline & 3 & The advertised product was very good. \\
\hline & 4 & The advertised product was very bad \\
\hline \multirow{4}{*}{ Attitude towards advertisement } & 5 & The tone of the advertisements is not very clear. \\
\hline & 6 & The ad had a very low quality \\
\hline & 7 & Get irritated as again the same advertisement comes. \\
\hline & 8 & Get on doing other activities as the advertisement comes. \\
\hline \multirow{3}{*}{ Trustable } & 9 & Do not Switch between channels when the ad is aired. \\
\hline & 10 & $\begin{array}{l}\text { Advertisements have brought about the change in concept of authenticity, trust and } \\
\text { loyalty. }\end{array}$ \\
\hline & 11 & Advertisements try to create attractiveness for the celebrity. \\
\hline \multirow[b]{2}{*}{ Product Planning } & 12 & Complete information in advertisements helps in planning for purchase. \\
\hline & 13 & $\begin{array}{l}\text { Advertisement gives me the information about the various products, features which I } \\
\text { am looking for. }\end{array}$ \\
\hline \multirow{4}{*}{ Emotional appeal } & 14 & The advertisement was entertaining \\
\hline & 15 & The advertisement was creative \\
\hline & 16 & The advertisement was touchy \\
\hline & 17 & The advertisement was creative \\
\hline \multirow{3}{*}{ Rational appeal } & 18 & The advertisement was informative. \\
\hline & 19 & The advertisement provide the updated and latest information \\
\hline & 20 & $\begin{array}{l}\text { The advertisement provides the information about the best investment alternatives to } \\
\text { invest. }\end{array}$ \\
\hline
\end{tabular}

List of extracted factors

\begin{tabular}{|c|c|c|c|c|c|c|}
\hline $\begin{array}{l}\text { Sr. } \\
\text { No } \\
\end{array}$ & Factors & Codes & \multicolumn{4}{|c|}{ Factor Loadings } \\
\hline \multirow{3}{*}{1} & \multirow{3}{*}{$\begin{array}{l}\text { Attitude to } \\
\text { product/service } \\
\text { provider }\end{array}$} & $\begin{array}{l}\text { In the advertisements we can easily access the infrastructure of the financial } \\
\text { provider. }\end{array}$ & .609 & & & \\
\hline & & $\begin{array}{l}\text { I became interested in the product after listening to/ seeing the } \\
\text { advertisement. }\end{array}$ & .669 & & & \\
\hline & & The advertised product was very good. & .756 & & & \\
\hline \multirow{5}{*}{2} & \multirow{5}{*}{$\begin{array}{l}\text { Attitude to } \\
\text { advertisement }\end{array}$} & The tone of the advertisements is not very clear. & & .810 & & \\
\hline & & The ad had a very low quality & & .835 & & \\
\hline & & Get irritated as again the same advertisement comes. & & 0.739 & & \\
\hline & & Get on doing other activities as the advertisement comes. & & & & \\
\hline & & & & 0.781 & & \\
\hline \multirow{3}{*}{3} & \multirow{3}{*}{ Trustable } & Do not Switch between channels when the ad is aired. & & & .596 & \\
\hline & & $\begin{array}{l}\text { Advertisements have brought about the change in concept of authenticity, } \\
\text { trust and loyalty. }\end{array}$ & & & .533 & \\
\hline & & Celebrity endorsing the advertisement leads to trust on the service provider & & & .721 & \\
\hline \multirow{6}{*}{4} & \multirow{2}{*}{ Product Planning } & Complete information in advertisements helps in planning for purchase. & & & & .725 \\
\hline & & $\begin{array}{l}\text { Advertisement gives me the information about the various products, features } \\
\text { which I am looking for. }\end{array}$ & & & & .688 \\
\hline & Eigen Value & & 2.32 & 1.64 & 1.24 & 1.14 \\
\hline & \% Variance & & 19.4 & 17.71 & 13.71 & 10.38 \\
\hline & $\begin{array}{l}\text { Cumulative \% } \\
\text { Variance }\end{array}$ & & 19.4 & 37.11 & 50.82 & 61.2 \\
\hline & $\begin{array}{l}\text { Scale Reliability } \\
\text { alpha }\end{array}$ & & 0.79 & 0.81 & 0.87 & 0.77 \\
\hline
\end{tabular}

